\title{
P12-07 廃菓物からの熱分解ガスによるガスエンジン発電稼動状兄
}

\author{
正 小沢 昇（川崎製鉄），清水益人（川崎製鉄） \\ 尾前純也（川崎製鉄），山田純夫（川崎製鉄）

\section{Operating condition of Gas-Engine with pyrolysis gas produced in the waste treatment process} \\ Noboru OZAWA, Masuto SHIMIZU,Jyunya OZAKI, Sumio YAMADA
Kawasaki Steel ,1 Kawasaki-cho,Chuo-ku,Chiba,260-0835,Japan
}

This paper describes the operating condition of $1.5 \mathrm{MW}$ gas engine system with pyrolysis gas produced in the waste gasification plant. This system started since Octorber 2001 at Kawasaki-Steel chiba works. The results shows the following four conclusions;

(1)Gas engine can operate continuously with pyrolsis gas of which LHV is between approximately 1500 and $2200 \mathrm{kcal} / \mathrm{m}^{3}{ }_{\mathrm{N}}$, enen when the fluctuation of $\mathrm{LHV}$ is approximately $3 \% / 30 \mathrm{~s}$.

(2)Electrical efficiency is $37 \%$ at $100 \%$ load and $33 \%$ at $50 \%$ load respectively.

(3)The concentration of dioxins in the exhaust gas was approximately $0.001 \mathrm{ng}-\mathrm{TEQ} / \mathrm{m}^{3} \mathrm{~N}$.

(4)The concentration of $\mathrm{NO}_{\mathrm{x}}$ in the exhaust gas is less than $100 \mathrm{ppm}\left(\mathrm{O}_{2}=0 \%\right)$ without $\mathrm{SCR}$.

Key Words: Gas-Engine,Pyrolysis,Waste,Fluctuation of LHV

\section{1. 緹}

川崎製鉄では、1999 年 9 月より千葉製鉄所構内 で施設規模 $300 \mathrm{t} / \mathrm{d}(150 \mathrm{t} / \mathrm{d} \times 2$ 系列)の廃棄物ガス化 溶融設備（川鉄サーモセレクト方式）を稼動開始 している ${ }^{1)}$ 。同施設では、一般廃棄物処理の実証試 験を終え、2000 年 4 月より産業廃棄物処理事業を 開始している。

川鉄サーモセレクト方式の特徵は、ダイオキシ ン類の発生を極限まで抑制し、水素と一酸化炭素 などを主成分とする回収ガス (熱分解ガス)、スラ グ、メタル、金属水酸化物、硫黄等の再資源化を することである。現在、廃棄物より製造した熱分 解ガスの全量を、施設が製鉄所内に設置されてい ることもあり、製鉄所の燃料ガスの一部として利 用している。この熱分解ガスの利用方法には燃料 ガスだけでなく、発電や化学原料にも利用するこ とが可能であり、その中でも分散型発電に利用す ることが最も一般的である。発電方式としては、 施設の処理規模に応じて蒸気タービン・ガスター ビン・ガスエンジン・燃料電池などが挙げられる
が、比較的小規模な処理施設では経済的で高効率 な面からガスエンジン発電が有望である。

しかし、一般的なガスエンジンの燃料は都市ガ スがほとんどで、近年バイオガスでの事例もある ${ }^{2)}$ が、双方ともメタンが主成分であり、今回の様な 水素・一酸化炭素を主成分とする熱分解ガスでの 実用化は国内ではない。そこで、廃棄物ガス化溶 融設備からの熱分解ガスでのガスエンジン発電特 性を把握することを目的に、2001 年 10 月に $1.5 \mathrm{MW}$ ガスエンジン発電装置を設置し稼動を開始した。

本報告では、熱分解ガスの特性、設備概要、運 転特性について述べる。

\section{2. 熱分解ガスの特性}

2-1 川鉄サーモセレクト方式の概要 ${ }^{1)}$

本ガスエンジンで燃料として使用する熱分解ガ スは川鉄サーモセレクト方式ガス化溶融設備から の回収ガスを適用する。figure1 に川鉄サーモセレ クト方式の概要を示す。廃棄物はごみピットで受 入れ、プレス装置で圧縮し、脱ガスチャンネルで 間接加熱により乾燥・熱分解処理して高温反応炉 


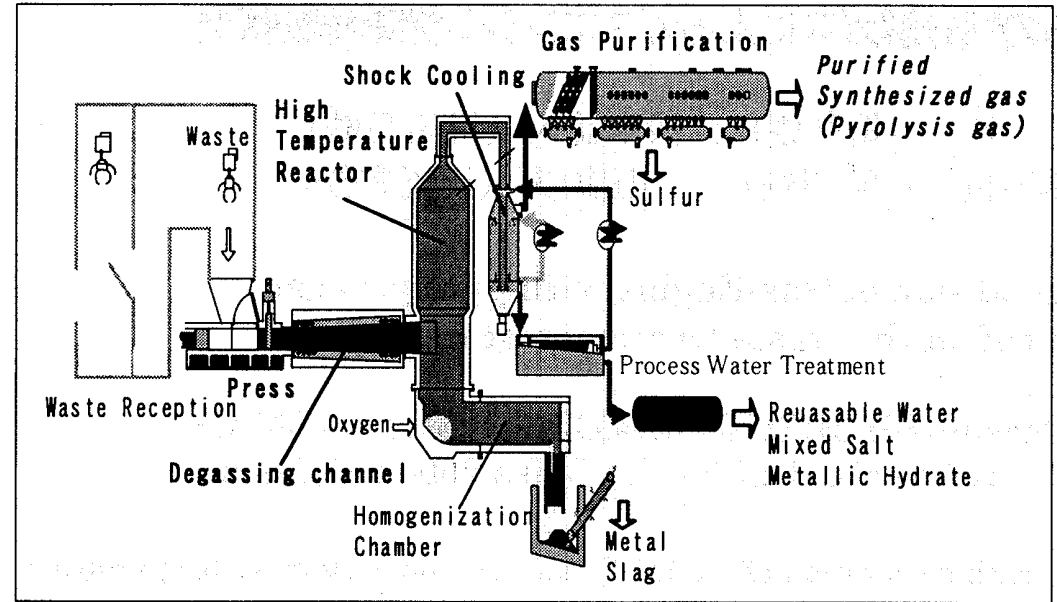

Figure1 Schematic diagram of Kawatetsu-Thermo Select process
へ装入される。高温反応炬では酸素と熱分解カー ボンとの反応で高温溶融され、炉上部ではガス中 のタール分やダイオキシン類およびその前駆体を 分解するために約 $1200^{\circ} \mathrm{C}$ で $2 \mathrm{~s}$ 以上滞留させる。

生成した熱分解ガスは、ダイオキシン再合成を 回避するために急冷し、ガス精製にて脱硫除湿す ることにより、清浄な燃料ガスとして回収される。

\section{$2-2$ 熱分解ガスの特徵}

熱分解ガスの主成分は水素、一酸化炭素、二酸 化炭素で、低位発熱量(LHV)は約 $2000 \mathrm{kcal} / \mathrm{m}^{3}{ }_{\mathrm{N}}$ で ある。Table1 に、熱分解ガスのガス組成の例を示 す。

Table1 Composition example

\begin{tabular}{|c|c|l|}
\hline $\mathrm{H}_{2}$ & 32.4 & vol\% \\
\hline $\mathrm{CO}$ & 43.1 & vol\% \\
\hline $\mathrm{CO}_{2}$ & 18.8 & vol\% \\
\hline $\mathrm{LHV}$ & 2120 & $\mathrm{kcal} / \mathrm{m}^{3}{ }_{\mathrm{N}}$ \\
\hline
\end{tabular}

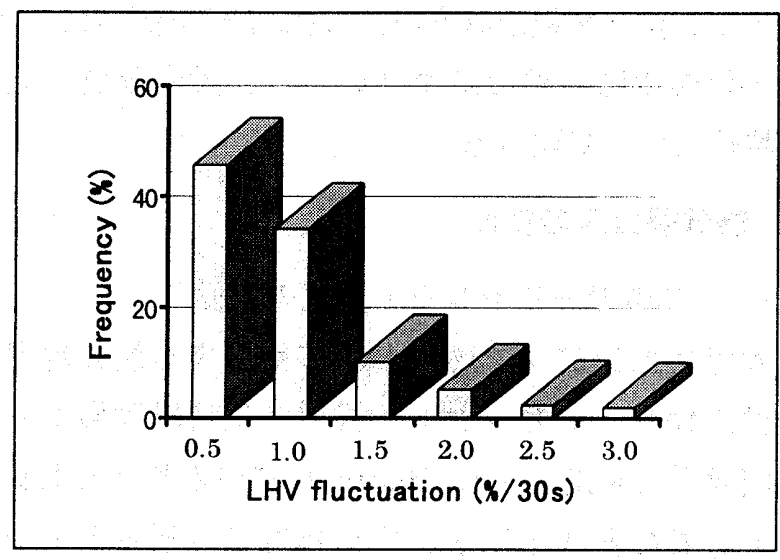

Figure2 Distribution of LHV fluctuation

また、熱分解ガスの発生状況は処理する廃棄物 の特性などに依存し変化する。Figure 2 に低位発熱
量変動率の構成分布を示 す。一般にガスエンジン 運転では、低位発熱量が ほぼ一定であることを前 提としているが、熱分解 ガスの低位発熱量の変動 率は最大 $3 \% / 30 \mathrm{~s}$ であるこ とが判る。熱分解ガスの 特徵を整理すると

(1)主成分は水素・一酸 化炭素・二酸化炭素

(2)低位発熱量は

約 $2000 \mathrm{kcal} / \mathrm{m}^{3}{ }_{\mathrm{N}}$

(3)低位発熱量の変動率は最大 $3 \% / 30 \mathrm{~s}$

である。したがって本研究の主要課題は、水素を 含有しかつ発熱量が変動するガスで安定運転を達 成することである。

\section{3. 設備概要}

$3-1$ 全体フロー

Figure3 に、本研究におけるガスエンジンシステ ムの全体フローを示す。

廃棄物ガス化溶融設備からの熱分解ガスの一部 を、ガス昇圧設備を介してガスエンジンに導入す るシステムとした。ガスエンジンからの排気ガス は排熱回収ボイラーで減温し煙突から排出し、附 帯としてガスエンジン本体や潤滑油などの各冷却 装置を配置した。低位発熱量変動に対して一定発 電量制御をすべく、ガス昇圧部で発熱量を計測し、 変動する発熱量に追従して空気比を制御するもの とした。 $3-2$ 設備主仕様

Table2 に今回導入したガスエンジンの主仕様を 示す。導入の際、国内外で水素を含有するガスで の運転実績を重視してメーカー選定した。

Table2 Specification of Gas-Engine

\begin{tabular}{|l|l|}
\hline Type & Lean-Burn Engine \\
\hline Cylinders & 20 \\
\hline Bore/Stroke & $190 / 220 \mathrm{~mm}$ \\
\hline Electrical output & $1507 \mathrm{~kW}(100 \% \quad$ Load $)$ \\
\hline Rotation & $1500 \mathrm{rpm}$ \\
\hline Maker & JENBACHER \\
\hline
\end{tabular}




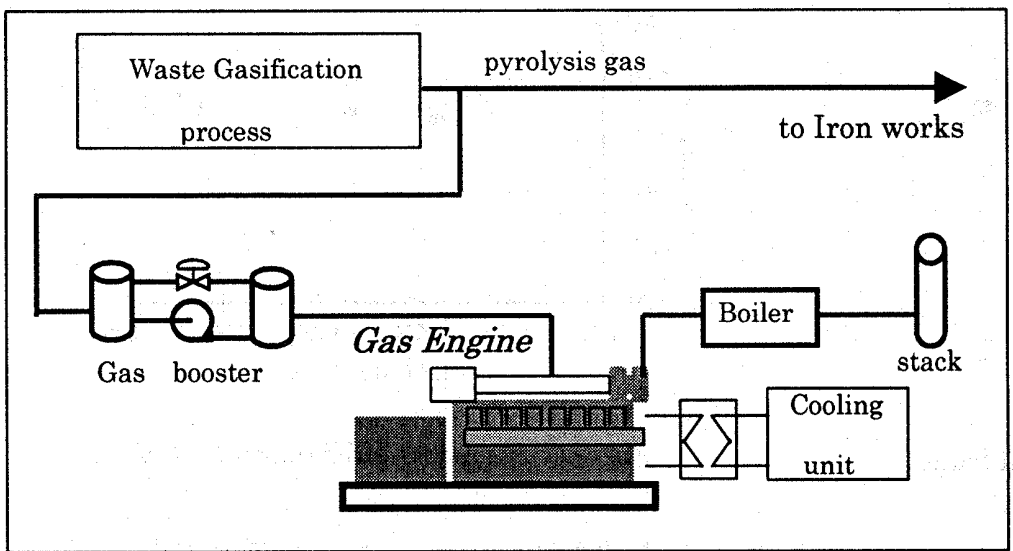

Figure3 Diagram of gas engine system

物を調整し熱分解ガスの低位発熱量 を変化させて実験し、低位発熱量が 約 $1500 \mathrm{kcal} / \mathrm{m}^{3}{ }_{\mathrm{N}}$ から約 $2200 \mathrm{kcal} / \mathrm{m}^{3}{ }_{\mathrm{N}}$ の範囲、および最大の変動率でも運 転が継続可能であることも確認した。 4-2 エネルギーバランス

運転と平行して、ガスエンジン各 冷却水の温度や排熱回収ボイラーで の蒸気発生量等を測定しエネルギー バランスを評価した。Figure5 に、 100\%負荷運転時でのエネルギーバラ

また、このガスエンジンは単室・火花点火式で 過給器を有している。発電能力は、今後の廃棄物 ガス化溶融設備における実機サイズでの運転特性 を把握するために、100\%負荷時 $1.5 \mathrm{MW}$ を選定し た。また、起動停止時の安定性を確保すべく、起 動時は都市ガス(13A)で開始し、低負荷運転を継続 した状態で熱分解ガスに切替ることとした。

\section{4. 運転特性}

\section{4-1 発電状況}

2001 年 10 月に、ガスエンジン発電装置の稼動 を開始した。運転はノッキング・バックファイヤ・ アフターファイヤー等の異常もなく順調である。

Figure4 に、典型的な発熱量（約 $2000 \mathrm{kcal} / \mathrm{m}^{3}{ }_{\mathrm{N}}$ ) でかつ変動を伴う場合での $1.5 \mathrm{MW}$ 発電状況例を示 す。Figure4より、変動する発熱量に対してガスエ ンジンでの熱分解ガス流量を変化させ、一定発電 を継続していることが判る。また、処理する廃棄

\section{ンスを示す。}

発電効率は $37 \%$ 達成し、従来の都市ガス仕様 ガスエンジン ${ }^{3)}$ と比較しても同等の発電効率を達成 した。同時に $35 \%$ 程度の熱回収（温水と蒸気）も 可能であり、本システムでの総合効率は $72 \%$ 程度 に達することを確認できた。

\section{$4-3$ 部分負荷特性}

各部分負荷運転における発電効率を評価した。

Figure6 に部分負荷と発電効率の相関を示す。 $50 \%$ 負荷での効率は約 $33 \%$ であ、100\%負荷時と比較 して、約 4\%の低下である。

4-4 低位発熱量と発電効率

ガスエンジンの低位発熱量に対する特性を把握 するために、廃棄物を調整し熱分解ガスの低位発 熱量を変化させ実験した。Figure7 に 100\%負荷運 転時の低位発熱量と発電効率の関係を示す。

Figure7 より、今回の低位発熱量の範囲ではほと んど発電効率は変化しないことが判った。

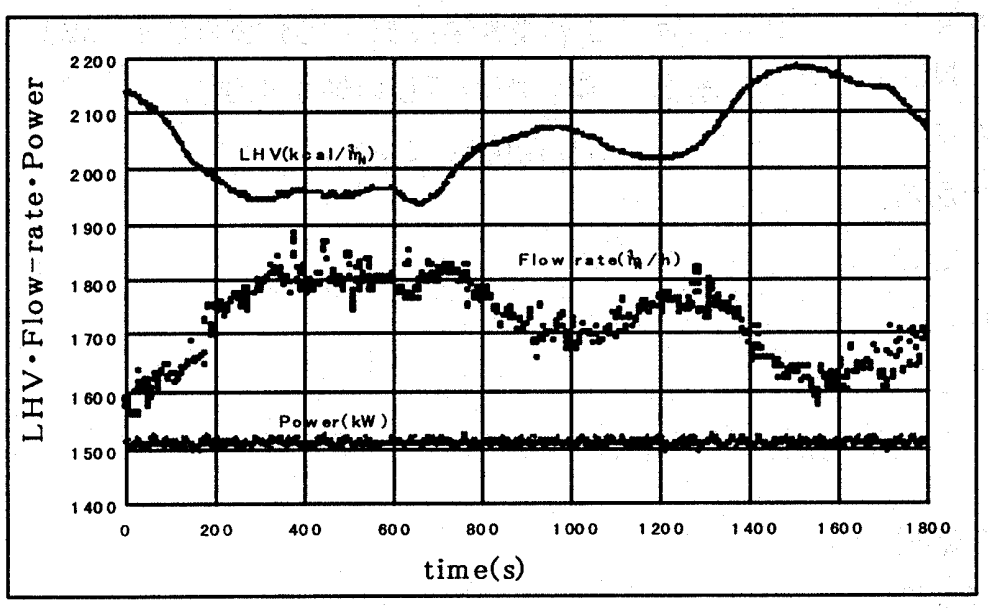

Figure 4 Example 1.5MW operating under typical LHV

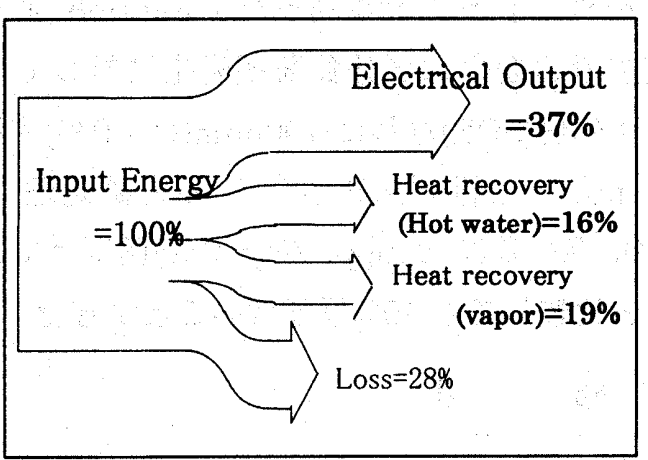

Figure5 Energy balance at $100 \%$ load 


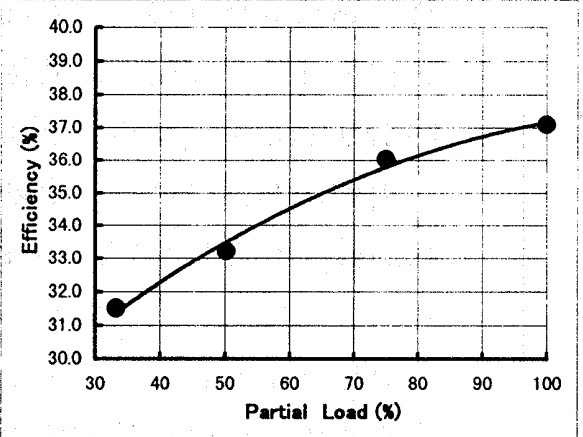

Figure6 Electrical efficiency in partial load

\section{4-5 排気ガス特性}

Table3 に排気ガス特性の測定例を示す。また、 各部分負荷運転時の $\mathrm{NO}_{\mathrm{x}}$ の発生状況を調查した。 Figure8 に部分負荷率と $\mathrm{NO}_{\mathrm{x}}$ の発生状況を示す。

Table3 Emission example

\begin{tabular}{|c|c|c|}
\hline Dust & $<0.5$ & $\mathrm{mg} / \mathrm{m}^{3}{ }_{\mathrm{N}}\left(\mathrm{O}_{2}=0 \%\right)$ \\
\hline NOx & $<100$ & $\mathrm{ppm}\left(\mathrm{O}_{2}=0 \%\right)$ \\
\hline DXNs & $\fallingdotseq 0.001$ & $\mathrm{ng}-\mathrm{TEQ} / \mathrm{m}^{3}{ }_{\mathrm{N}}$ \\
\hline
\end{tabular}

Remark: DXNs=PCDDs+PCDFs+co-PBCs

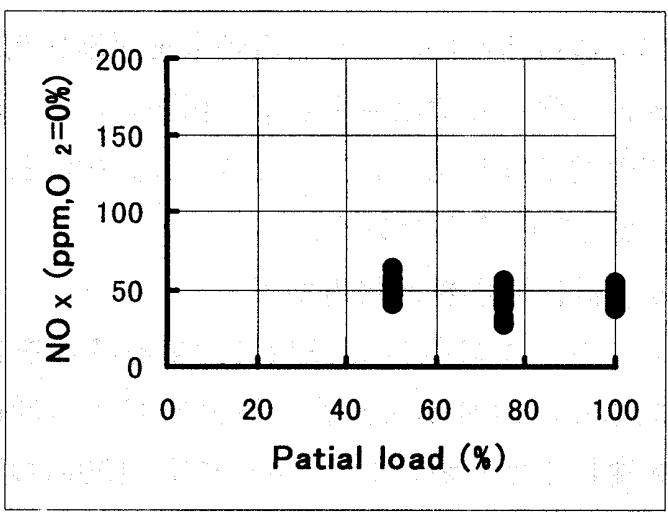

Figure8 $\mathrm{NO}_{\mathrm{x}}$ value in partial load

Table3 より各值とも充分に小さい結果を得た。 ダイオキシン類の毒性等量については、ダイオキ シン類対策特別措置法の規制值 $0.1 \mathrm{ng} \cdot \mathrm{TEQ} / \mathrm{m}^{3}{ }_{\mathrm{N}}$ 以 下を満足することが判った。Figure8 より、 $\mathrm{NO}_{\mathrm{x}}$ 発生量の変化は部分負荷率変化に対して小さく、 脱硝処理(SCR)なしに $100 \mathrm{ppm}\left(\mathrm{O}_{2}=0 \%\right)$ 未満である。 都市ガス仕様ガスエンジンの脱硝処理なしでの $\mathrm{NO}_{\mathrm{X}}$ 発生量は $200 \mathrm{ppm}\left(\mathrm{O}_{2}=0 \%\right)$ 程度 $\left.{ }^{4}\right)$ であり、こ れと比較しても $50 \%$ 程度低いことが確認できた。

\section{5. 結言}

廃棄物ガス化溶融設備からの熱分解ガスを燃料 として、2001 年 10 月より $1.5 \mathrm{MW}$ ガスエンジン発

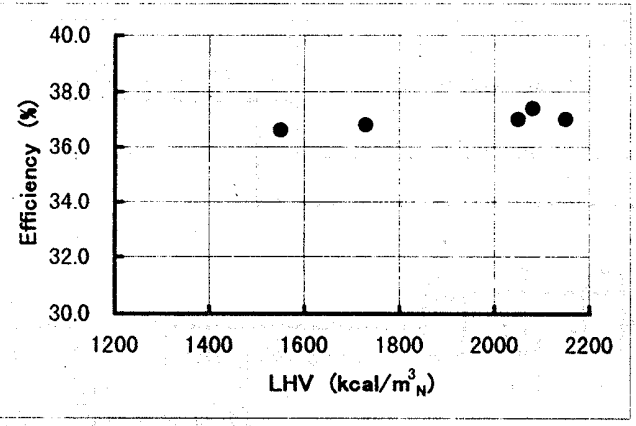

Figure7 Electrical efficiency vs. LHV

電装置を稼動開始し、以下の知見を得た。

(1)熱分解ガスの低位発熱量が約 1500 $2200 \mathrm{kcal} / \mathrm{m}_{\mathrm{N}}^{3}$ の籁囲で、発熱量変動が $3 \% / 30 \mathrm{~s}$ 程度でも、一定発電運転の継続は可能である。

(2) $100 \%$ 負荷時の発電効率は $37 \% て ゙ 、 50 \%$ 負荷 時 $33 \%$ 程度であり、都市ガス仕様ガスエンジ ンと比較しても同等な発電効率である。

(3)排気ガス中のダイオキシン類は 0.001ng$\mathrm{TEQ} / \mathrm{m}^{3}{ }_{\mathrm{N}}$ 程度である。

(4)排気ガス中の $\mathrm{NO}_{\mathrm{x}}$ 発生量は、脱硝処理なしに $100 \mathrm{ppm}\left(\mathrm{O}_{2}=0 \%\right)$ 末満である。

\section{6. 謝辞}

本研究の一部は、新エネルギー・産業技術総合 開発機構における平成 12 年度と平成 13 年度の 産業技術実用化開発費補助事業に採択され実施し たものである。関係各位に、感謝致します。

7. 参考文献

1 ）三好；化学装置、40 (1998) 7、p38

2) 石川 ; 省エネルギー、(1992)、 p14

3 ）三浦；日本機械学会誌、104 (2001) 4、p29

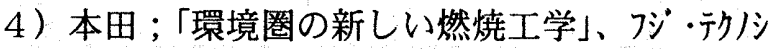
仢L(1999)、p681 